\section{A NOVEL CLASS OF DIKETOPIPERAZINES}

R. L. DeVault and William RosenbrooK, Jr.

Department of Microbial Chemistry, Abbott Laboratories,

North Chicago, I11., 60064, U.S.A.

(Received for publication May 26, 1973)

In the course of our screening for antibiotics, NRRL 3888, an unidentified* fungus, was observed to produce three new substances related to the epidithiadiketopiperazines such as glio$\operatorname{toxin}^{1)}$, sporidesmin ${ }^{2)}$, and aranotin ${ }^{3,4}$.

The following structures were determined for these metabolites: 2-benzyl-1, 4-dimethyl-5hydroxymethyl-2, 5-epi-dithia-3, 6-diketopiperazine (I), 2-benzyl-1, 4-dimethyl-5-hydroxymethyl-2, 5-epitrithia-3, 6-diketopiperazine (II), and the bisdethiadi(methylthio) analogue of $\mathbf{I}$ (III).

These structures are of particular interest because they represent the benzyldiketopiperazine suggested by Neuss, et al., $1968^{5}$ as a late intermediate in the biogenesis of gliotoxin type and aranotin type metabolites. The possibility of such an intermediate was later corroborated by the finding that phenylalanine and not $\mathrm{m}$ tyrosine is a precursor of both gliotoxin ${ }^{6)}$ and the aranotins. ${ }^{7}$ ) The discovery of these three metabolites, notwithstanding the obvious limitations of such a statement, lends some support to the proposed biosynthetic scheme and at least shows that synthesis of the dithiadiketo-<smiles>CN1C(=O)C2(CO)SSC1C(Cc1ccccc1)N2C</smiles><smiles>CN1C(=O)C2(CO)SSC1C(Cc1ccccc1)N2C</smiles><smiles>CN1C(=O)C(C)(Cc2ccccc2)N(C)C(=O)C1(C)CO</smiles>

piperazine moiety can preceed oxidation of the phenyl group and formation of the pyrrolidine ring.

The structures of these metabolites were deduced from proton magnetic resonance (pmr) and mass spectral data and from the chemical correlation between these metabolities and appropriately selected reference compounds. In the pmr spectrum of I (Fig. 1) the signal at $\tau 2.70$ represents five aromatic protons. Singlet resonances at $\tau 6.80$ and 7.04 arise from the $4-\mathrm{N}$ and $1-\mathrm{N}-\mathrm{CH}_{3}$ groups. Resonances arising from

Fig. 1. The proton magnetic resonance spectrum of compound $\mathbf{I}$ in $\mathrm{CDCl}_{3}$ at $60 \mathrm{MHz}$.

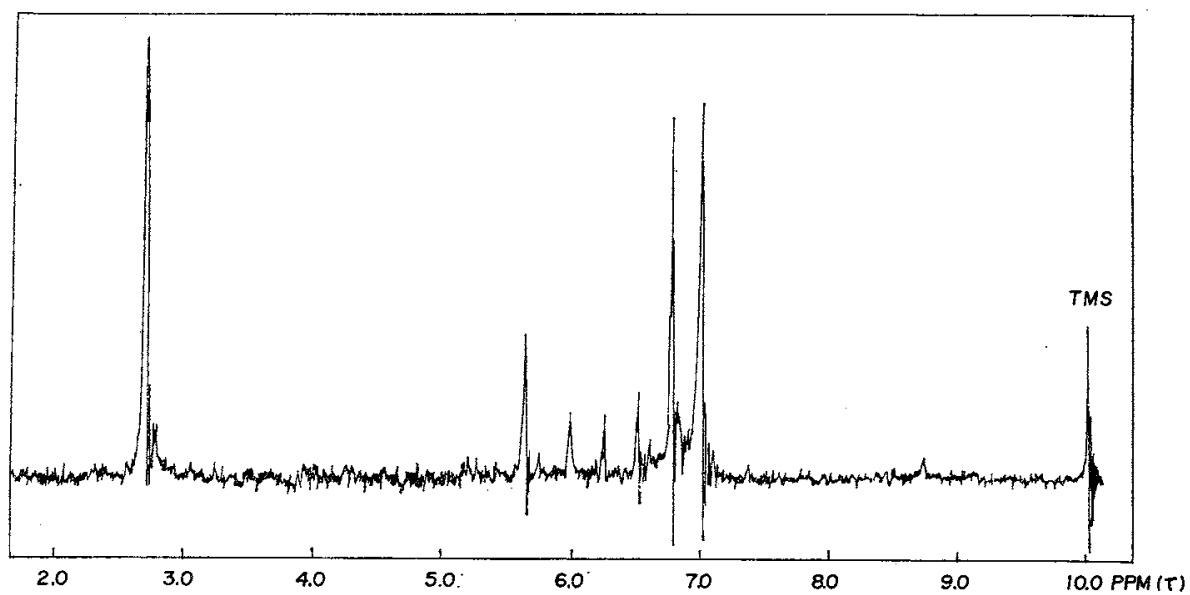

* In spite of considerable effort generously afforded by the Centraalbureau voor Schimmelcultures, Baarn, the Netherlands, NRRL 3888 remained sterile, therefore making it impossible to identify the fungus. 
Table 1. Antifungal spectra

\begin{tabular}{l|c|c|c}
\hline \multicolumn{1}{c|}{ Test organism } & \multicolumn{3}{|c}{ MIC (mcg/ml) } \\
\cline { 2 - 2 } & Gliotoxin & Compound I & Compound III \\
\hline Candida albicans 10231 & 12.5 & 6.2 & 12.5 \\
Epidermaphyton floccosum Wise & 3.1 & 0.78 & 3.1 \\
Microsporum canis VB & 3.1 & 1.56 & 6.2 \\
Microsporum gypseum 1236 & 25 & 6.2 & 25 \\
Trichophyton mentagrophytes 9533 & 3.1 & 0.78 & 6.2 \\
Microsporum audouinii 10216 & 6.2 & 1.56 & 12.5 \\
Trichophyton tonsurans 10217 & 3.1 & 1.56 & 6.2 \\
Trichophyton rubrum Robinson & 6.2 & 6.2 & 12.5 \\
\hline
\end{tabular}

the two methylene groups and observed as a singlet at $\tau 5.65$ for the $-\mathrm{CH}_{2} \mathrm{OH}$ group and an $\mathrm{AB}$ quartet with doublets at $\tau 5.90$ and $6.39\left(J_{\mathrm{AB}}\right.$ $=16 \mathrm{~Hz}$ ), attributable to the benzylic- $\mathrm{CH}_{2}$, are similar to those reported for dehydrogliotoxin ${ }^{8,9)}$. The additional singlet observed in this region at $\tau 6.52$ is caused by residual solvent methanol. The $\mathrm{OH}$ resonance was not observed. The singlets produced by the $\mathrm{N}-\mathrm{CH}_{3}$ protons shifted to 6.9 and $6.93 \mathrm{ppm}$ in the pmr spectrum of II, while III produced additional signals at $7.7\left(\mathrm{~s}, \mathrm{~S}-\mathrm{CH}_{3}\right)$ and $7.85\left(\mathrm{~s}, \mathrm{~S}-\mathrm{CH}_{3}\right)$.

The mass spectra of substances I, II, and III exhibited relatively simple fragmentation. I produced a weak molecular ion m/e 324 $\left(\mathrm{C}_{14} \mathrm{H}_{16} \mathrm{~N}_{2} \mathrm{O}_{3} \mathrm{~S}_{2}\right)$ and a strong fragment ion at $m / e 260\left(\mathrm{~m}-\mathrm{S}_{2}\right)^{+}$, while II produced weak ions at $m / e 356,324$, and 292 which were interpreted to represent a stepwise desulfurization of a homologue of I. The bisdethiadi (methylthio) analogue, III, produced a weak molecular ion, m/e $354\left(\mathrm{C}_{10} \mathrm{H}_{22} \mathrm{~N}_{2} \mathrm{O}_{3} \mathrm{~S}_{2}\right)$, and strong fragment ions at m/e $307\left(\mathrm{C}_{15} \mathrm{H}_{18} \mathrm{~N}_{2} \mathrm{O}_{3} \mathrm{~S}\right)$ and $m / e 260$ $\left(\mathrm{C}_{14} \mathrm{H}_{18} \mathrm{~N}_{2} \mathrm{O}_{3}\right)$. The mass spectra of $\mathrm{I}, \mathrm{II}$, and III each exhibited fragment ions at $m / e \quad 242$ $\left(\mathrm{C}_{14} \mathrm{H}_{14} \mathrm{~N}_{2} \mathrm{O}_{2}\right), 231\left(\mathrm{C}_{13} \mathrm{H}_{15} \mathrm{~N}_{2} \mathrm{O}_{2}\right)$, and 91 (trophylium ion).

Versus a series of dermatophytes, as shown in Table 1 , compounds $\mathbf{I}$ and $\mathbf{I I}$ are relatively potent antifungal antibiotics whose spectra and potency are very similar to that of gliotoxin. The toxicity of these compounds, however, is also similar to that of gliotoxin $\left[\mathrm{LD}_{50}\right.$ (mouse, i.p.): I, $35 \sim 50 \mathrm{mg} / \mathrm{kg}$; II, $24 \sim 40 \mathrm{mg} / \mathrm{kg}$ ]. Also like gliotoxin, I and II exhibit antibacterial activity primarily against Gram-positive organisms. Compound III, like the bisdethiadi (methylthio) analogues reported in the litera- ture, ${ }^{b)}$ is not active against fungi and bacteria and is relatively non-toxic to mice $\left[\operatorname{LD}_{50}\right.$ (i.p.): $>200 \mathrm{mg} / \mathrm{kg}$.

\section{Acknowledgement}

The authors wish to thank Dr. R. EGAN for pmr spectra, Dr. M. Levenberg for mass spectra, Ms. M. JACKSON and Mr. C. S. W ADLEY for in vitro data, and particularly Mr. W. ANDREs for many helpful suggestions.

\section{References}

1) BELL, M. R.; J. R. JOHNSON, B. S. WILDI \& R. B. WOODWARD: The structure of gliotoxin. J. Am. Chem. Soc. 80: 1001, 1958.

2) Ronaldonon, J. W.; A. Taylor, E. P. White \& R. J. AbraHAM: Sporadesmins. I. Isolation and characterization of sporadesmin and sporadesmin B. J. Chem. Soc. 1963: 3172 3180, 1963.

3) Nagarajan, R.; L. L. Huckstep, D. H. Lively, D. C. Delong, M. M. Marsh \& N. Neuss: Aranotin and related metabolites from Arachniotus aureus. I. Determination of structure. J. Am. Chem. Soc. 90: 2980 2982, 1968

4) Trown, P. W.; H.F. Lindh, K.P. Milstrey, V. M. GALlo, B. R. MAYBERRY, H. L. LindSAY \& P.A. MILLER: LL-S88 $\alpha$, an antiviral substance produced by Aspergillus terreus. Antimicr. Agents \& Chemoth. -1968: 225 228, 1969

5) Neuss, M.; L.D. Boeck, D. R. Brannon, J.C. Cline, D.C. Delong, M. Gorman, L.L. HuCkstep, D. H. Lively, J. Mabe, M. M. Marsh, B. B. Molloy, R. Nagarajan, Janet D. Nelson \& W.M. Stark: Aranotin and related metabolites from Arachniotus arueus (Eiclam) Schroeter. IV. Fermentation, isolation, structure elucidation, biosynthesis, and antiviral properties. Antimicr. Agents \& Chemoth. -1968: 213 219, 1969

6) Bu'Lock, J.D. \& A. P. RyLES: The biosynthesis of the fungal toxin gliotoxin; the origin of 
the "extra" hydrogens as established by heavyisotope labeling and mass spectrometry. Chem. Comm. 1970: 1404 1406, 1970

7) Brannon, D. R.; J. A. Mabe, B. B. Molloy \& W.A. DAY: Biosynthesis of dithiadiketopiperazine antibiotics: Comparison of possible aromatic amino acid precursors. Biochem. Biophys. Res. Comm. 43: 588 594, 1971
8) Lowe, G.; A. TAYlor \& L. C. VINING: Sporidesmins. VI. Isolation and structure of dehydrogliotoxin a metabolite of Penicillium terlikowskii. J. Chem. Soc. 1966: 1799 1803, 1966.

9) Brewer, D.; R. Rohman, S. SAFe \& A. TAylor: A new toxic metabolite of Pithomyces chortarum related to the sporidesmins. Chem. Comm. 1968: 1571,1968 